\title{
THE ICONIC ONTOLOGY OF ST. MAXIMUS THE CONFESSOR
}

\author{
Aleksandar DJAKOVAC*
}

\begin{abstract}
St. Maximus the Confessor claims that the logos of created beings represents their essence as an icon. This claim gives us the opportunity to understand the term essence as a dynamic reality, and not as a given static. Essence is not something that the being is, but what it is supposed to be. The idea of icon is herein present as ultimately ontological. The icon is no mirror of reality, but rather its eschatological realization. That which will be uncovers the truth of the being. This way, St. Maximus founded a dynamic ontology, which is a fundamental step away from the Hellenic heritage. The equalization of the essence of beings and the icon is only possible in an Eucharistic view of the world, wherein the Eucharist represents in an iconic way the presence of the eschatological truth in history.
\end{abstract}

Keywords: logos, essence, icon, Eucharist, eschaton

\section{Paradeigma, Mimesis, Anagogy}

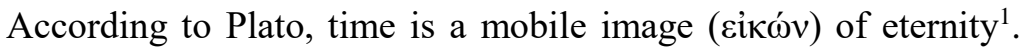
The mobility of the image is a sign of its ontological secundarity. The truth of things is in that which is eternal and immobile, which therefore has, because of that, ontological priority. Plato specifically tries to clarify the relation between icon and paradeigma $(\pi \alpha \rho \alpha \delta \varepsilon \varepsilon \gamma \mu \alpha)$. The cosmos was fashioned after an eternal model ${ }^{2}$. For Plato, icon is either imitation or imagination. "We must remember that there were to be two parts of the image-making class, the likeness-making and the fantastic

\footnotetext{
* PhD, Assistant Professor, University of Belgrade (Faculty for Orthodox Theology), Belgrade, Serbia.

${ }^{1}$ Plato, Timaeus 38b 6-c3.

${ }^{2}$ Eric Voegelin, Plato, University of Missouri, 2000, p. 195.
} 
( $\alpha \nu \tau \alpha \sigma \tau 1 \kappa o ̀ v)$, if we should find that falsehood really ( $\left.\psi \varepsilon \tilde{v} \delta \circ \varsigma^{\circ} \nu \tau \omega \varsigma\right)$ existed and was in the class of real being"3. Icon can therefore either be a shadow of reality, or an illusion, and it depends fully on reality, though reality itself is understood as transcendent, as $\dot{\varepsilon} \pi \varepsilon \dot{\varepsilon} \varepsilon v v \alpha$

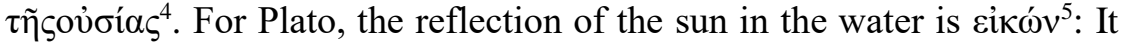
is understood as essentially mimetical. According to Philostratus, if we don't have an idea about what is represented in a picture, we can't enjoy $i^{6}$. The world we see is not simply a mirroring of the transcendent one. Its imperfection is mirrored in the multiplicity which should rather go in the direction of radical simplicity ${ }^{7}$. The highest goal of humanity is to become like God, its ideal ${ }^{8}$. In Neo-Platonism, the icon still represents a higher reality. According to Plotinus, the soul is the icon of $n o u s^{9}$, while matter is the icon of being ${ }^{10}$. Damascius ${ }^{11}$ claims that the soul has to imprint its own image into the body. The material shows itself thus as something which is twice indirect.

In the Christian interpretation there are certain dilemmas in the understanding of icon from the beginning, which oscillate between the Biblical view and the Hellenic one. Ramelli notes that Clement of Alexandria takes over Plato's definition of time, but with a meaningful

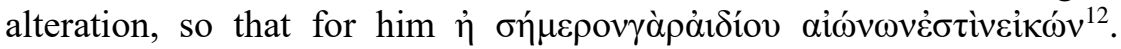
This age ( $\alpha i \omega v)$ shows itself as being not simply a mirroring of the

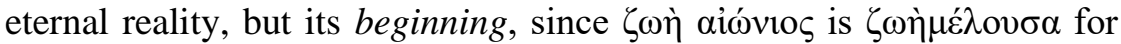
it. For Clement, the icon designates participation in that which it represents. Man was created according to the icon of God, and that means that man takes part in God's reality. God created man and

${ }^{3}$ Sophist 266DE.

${ }^{4}$ Republica 6.509B.

${ }^{5}$ Phoedo 99D.

6 Vita Apollonii II.22; Göran SöRBOM, "The Classical Concept of Mimesis", in A Companion to Art Theory, Wiley-Blackwell, 2007, p. 21.

7 Thomas M. JEAnNot, "Plato and Aristotle on Being and Unity", The New Scholasticism, no. 4/1986,p. 426.

${ }^{8}$ Theaetetus $176-177$.

${ }^{9}$ Enneades 5, 8, 12.

${ }^{10}$ Enneades I, 8,3.

11 in Phaedo III, 4.

12 Protrepticus 9,84,6; Ilaria RAMELli, The Christian Doctrine of Apokatastasis: A Critical Assessment from the New Testament to Eriugena, BRILL, 2013, p. 130. 
inspired him with his spirit. That which belongs to God in a man is that what makes him an icon of $\operatorname{God}^{13}$. Origen transfers the Platonistic transcendence onto God, so for him "God does not even participate in being" 14 . Especially not in a material way, which is why Origen very energetically dismisses the idea that man was created as an icon of God in a corporal way. "We do not understand, however, this man indeed whom scripture says was made according to the image of God, to be corporeal. For the form of the body does not contain the image of God"15. Celsus cites the teaching of the Scripture about Imago Dei to show that the Christian criticism towards the Hellenic anthropomorphism is inconsistent ${ }^{16}$. Origenes counters that, but his reasons are not only of an apologetic nature. He essentially accepted the neo-platonistic despisal of the material as a pale icon of a higher reality. He understands Jesus' words "He who has seen Me has seen the Father" $(\mathrm{Jn} 14,9)$ in that way. Jesus as an icon of the Father does not represent a stable reality, which is why He shows Himself to everyone in a different way, according to their inner abilities ${ }^{17}$. For him, icon is an ontological $\mu$ í $\eta_{\sigma \iota \varsigma}$, "of moral and voluntary assimilation to the archetype"18. Based on Origen's understanding, Evagrius develops the idea of the imageless prayer, as a perfect contemplative method which leads to true $\theta \varepsilon 0 \lambda$ y $^{\prime} \alpha^{19}$. In the Apophthegmata Patrum, we can find a warning by Abba Sopatros that a monk should not allow women in his cell, he shouldn't read apocrypha, and should not "think about icons" 20 . It seems that the accusations against Origenists, that they were the ideological

13 Pedagogus I, 3; cf., Nonna Verna HARRISON, "The human person as image and likeness of God", in The Cambridge Companion to Orthodox Christian Theology, (Edited by Mary B. Cunningham and Elizabeth Theokritoff), Cambridge University Press, 2009, p. 78.

${ }^{14}$ Contra Celsum VI, 64.

${ }^{15}$ Homiliae in Genesim 1, 13.

${ }^{16}$ Contra Celsum VII, 62

${ }^{17}$ Contra Celsum II, 64

18 John A. McGuckin (ed.), The Westminster Handbook to Origen, Westminster John Knox Press, 2004, p. 133.

19 Columba STEwart, "Imageless Prayer and the Theological Vision of Evagrius Ponticusm”, in Journal of Early Christian Studies, no.2/2001, p. 178.

${ }^{20}$ PG 65, 413A. Though there ware later 'purges', in many sayings one can recognize traces of Origenism. 
inspirers of iconoclasm, maybe weren't unfounded.

We also have a different tradition, founded in the Holy Scripture, which sees the icon in the light of the eschatological reality. Stephanus of Gabala said that the cross is an icon of the immortal kingdom

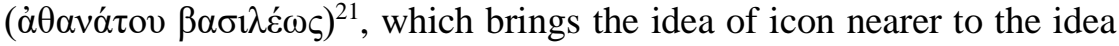
of symbol, but takes it away further from the platonistic meaning. According to Kittel, such a meaning of the idea of icon is founded in the New Testament: "In the NT the original is always present in the image.

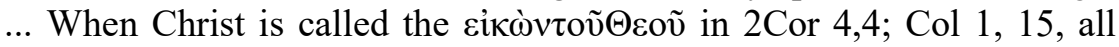
the emphasis is on the equality of the cikòv with the original" ${ }^{22}$. But even the Logos himself, as an icon of the Father, is at the same time an

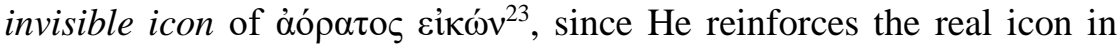
man, which had been blurred by $\sin ^{24}$.

Still, there was no strict distinction between the platonistic and Christian understanding of the icon. For Gregory Nazianzene, the icon is

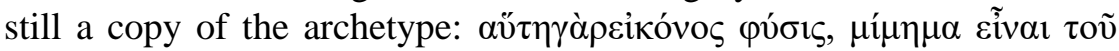
$\dot{\alpha} \rho \chi \varepsilon \tau \tau^{\prime} \pi \mathrm{ov}^{25}$. The Cappadocians didn't have a developed theology of the icon, but we can understand the meaning of the concept. So Gregory of Nyssa, while speaking of human nature which was created in accord with the icon of God, says:

"For as, in men's ordinary use, those who make images of princes both mould the figure of their form, and represent along with this the royal rank by the vesture of purple, and even the likeness is commonly

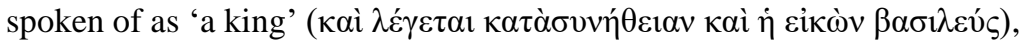
so the human nature also, as it was made to rule the rest, was, by its likeness to the King of all, made as it were a living image, partaking with the archetype both in rank and in name" 26 .

Gregory accents likeness as the basic attribute of icon, and by doing that, he stays in the platonist tradition. But, his claim that the icon

${ }^{21}$ Geoffrey H. LAMPE, A Patristic Greek Lexicon, Oxford University Press, 1969, p. 411.

${ }^{22}$ GerhardKitTEL, Theological Dictionary of the New Testament, William B. Eerdmans Publishing Company, 1965, p. 395.

23 Athanasius, De decretis, 27.

${ }^{24}$ Ilaria RAMELLI, The Christian Doctrine of Apokatastasis, p. 197.

${ }^{25}$ Orationes 36.

${ }^{26}$ De hominis opificio: PG 44, 136C. 
of the emperor by likeness will be called emperor, too, and that the human nature by the same principle is partaking with the archetype both in rank and in name, gives a base for a development which we will find later in the works of St. Maximus.

Dionysius the Areopagite sees the icon as an anagogical representation of man's ascension to unity with God, with the whole world being included in that hierarchy. "Material lights are images of the outpouring of an immaterial gift of light"27. The world being an icon is an old platonistic idea, but the anagogical understanding of the icon was something new $^{28}$. The Areopagite sees the anagogical model in a hierarchical ladder: "Proportionately to ourselves, as I said, our hierarchy is somewhat symbolical, needing sensible things for our more divine 'anagogy' from them to the intelligible things" 29 . Maximus the Confessor will introduce fundamental changes into this concept, basing them on the ideas of the Cappadocians and the Areopagite scriptures.

\section{Shadow and Icon}

In the teachings of St. Maximus the Confessor we see a meaningful distinction between shadow and icon. He says that "the

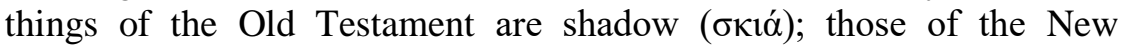

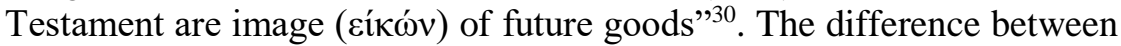
shadow and icon is, for Maximus, fundamental. What the icon represents in the platonistic tradition is shadow for him. A shadow is a representation of a higher reality which it implies, and in which it partakes only in a passive way ${ }^{31}$. On the other hand, the icon implies future goods, by already partaking in those goods. The meaning of the idea of icon nears here the meaning of the idea of symbol, which is a bridge between this side and the other side through identification with

${ }^{27}$ De celesti hierarchia: PG 3, 121D-124A.

28 Though Rorem successfully made a connection to Iamblichus (Paul RoREM, "Iamblichus and the Anagogical Method in Pseudo-Dionysius' Liturgical Theology", in Studia Patristica, no.1/1982, p. 453-460).

${ }^{29}$ De ecclesiastica hierarchia: PG 3, 377A.

${ }^{30}$ Capita Theologica et Oeconomica I, 90: PG 90, 1120D.

${ }^{31}$ Such a meaning of shadow we can find in the works of Iamblichus, who says that shadows follow bodies, but that they don't have their own hypostasis; IAMBLICHUS, De communi mathematica scientia 8.6. 
that what it represents. The Hellenic meaning of symbol is based on natural cycles, like the seasons, while the Christian symbolism is based on the fact of the Incarnation as a supernatural event, because of which symbolism can't be based on natural properties ${ }^{32}$.

In a scholium on the Areopagite we find the following formulation: truth is a thing of the future age - $\dot{\alpha} \lambda \dot{\eta} \theta \varepsilon 1 \alpha \quad \delta \dot{\varepsilon} \dot{\eta}$

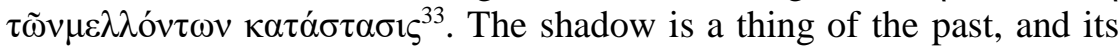
destiny is to vanish, since it has no content, while the icon implies presence $^{34}$. The presence is historical, though in history the eschatologicsal fullness of the parousia still isn't fully realized. All historic events get their meaning from the future, not from the past, so that the symbol in Christian thought is mainly eschatological. The Areopagite sees icon and symbol as an imprint (picture) of a parallel reality, while St. Maximus moves this perspective towards eschatology.

\section{The logoi of the icon}

To understand Maximus' moving of the understanding of the iconic from anagogic to eschatological, we have to remember his teachings on logoi. Logoi are equal to God's predestination

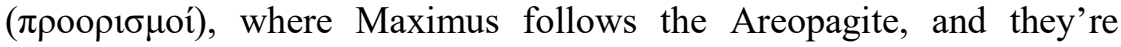
designated as God's wishes $(\theta \varepsilon i \tilde{\alpha} \theta \varepsilon \lambda \eta \dot{\mu} \alpha \tau \alpha)$ : “we say that God knows existent things as the products of his own acts of will" 35 . The key dimension of Maximus' understanding of the divine logoi is tied to Christology. Logos, Son of God, Second Person of the Holy Trinity, is the One who collects all the logoi of nature in himself. Logos himself is the inner Logos of the logoi of nature, which means that in Him and through Him the final meaning of everything in existence is realized. The Logos incarnate shows the true logoi of the nature of everything created, but the logoi of the Divine remain inaccessible, since Logos

32 John ZiZIOUlas, The Eucharistic Communion and the World, Bloomsbury T\&T Clark, 2011, p. 86.

33 Sch. in eccl. hier. 3, 3:2. Though it was probably not written by Maximus, the scholium is written in his spirit.

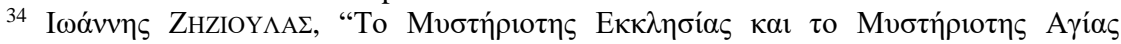

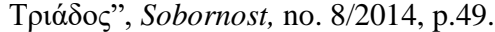

${ }^{35}$ Ambiquorum liber: 7, PG 91, 1085B. 
communes with us by hypostasis and not by nature. The logoi of nature aren't equal to God the Logos, since $\mathrm{He}$ as God transcends them infinitely, but $\mathrm{He}$ is the paradigm of the logoi of nature, and as the One in Whom the creation and Creator unite, He is their realization. The Son of God, the eternal Logos is, according to Maximus, the One who holds all the logoi:

"He (the divine Logos) held the logoi of all things which subsisted before the ages, and by His gracious will brought the visible and invisible creation into existence out of nothing in accordance with these logoi; by word (logos) He made, and continues to make, all things at the proper time, universals as well as particulars" 36 .

Maximus' logoi differ from platonistic ideas exactly because they do not represent some eternal parallel reality. When we understand logoi this way, we can see that the process of the world's creation is still not finished, and that the final truth of the world will not be realized before the eschatological Kingdom of God. Maximus' understanding of logoi gives us a particular understanding of the icon. After Christ, history is not a shadow anymore, not an empty mirror of reality, but an icon, representing a part of what will show itself as the final truth of the world in the Eschaton.

\section{Nature: necessity and freedom}

Maximus follows the tradition of Alexandria in his understanding of created nature. St. Athanasius already understood that nature is mortal because it was created, and that salvation happens on an ontological level. The nature of created things is weak and mortal because it was made out of non-being, so that without the Savior, there was danger that "the Universe should be broken up again into nothingness" "37. Through partaking in the Mystery of Christ, the created nature is supposed to overcome its own limits which exist because of the fact that it is created. When we read St. Maximus: "The purpose of the giver of the commandments is to free man from the world and from

\footnotetext{
${ }^{36}$ Ambiquorum liber : 7, PG 91, 1085A.

${ }^{37}$ Contra Gentes, 41, 2-3.
} 


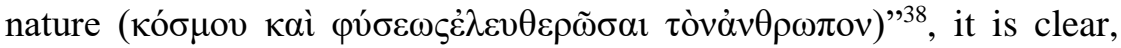
that the salvation of man from nature doesn't only mean salvation from death, but from the mortal way of existence. Death is not something added from the outside to the created nature, but something that is inherent for it, and therefore man is supposed to be freed from his own nature, which is designated as the one which enslaves. "'The mystery of the salvation' is brought about by things that are willed, and not by the things found under the tyranny (of nature)"39.

In another place, we find important and much more precise formulations by Maximus:

"Nature is, according to the philosophers, the principle of movement and rest; but for the Fathers it is genus of the many and different members, applied to what something is. Ousia is, according to the philosophers, a self-existing thing which does not need something else in order to be constituted; but according to the Fathers, it is the natural being of many and different hypostases" $"$.

Maximus tells us here that, according to philosophers, nature is a principle of movement and rest. The nature represents a diastemic way of existence, which is separation and dissemination ${ }^{41}$. Nature is that which is formed and determined by decay. But, according to the Fathers, says Maximus, nature refers to genus and designates that what something is. What something is is not determined by the principle of movement and rest. That means that what something really is, is not determined by its special-temporality. Otherwise, death would be the only possible way of existence for created beings. Nature not being necessarily diastemic, according to the Fathers, means that it is ecstatic. Nature has in itself a potential to overcome itself and to overcome the limits of its own createdness. So essence (ov̉oía), according to

${ }^{38}$ Epistole. 9, PG 91, 448C.

39 Orationis dominica eexpositio: PG 90, 880B; John Panteleimon MANOUSSAKIS, For the Unity of All: Contributions to the Theological Dialogue between East and West, Cascade Books, 2015, p. 75.

40 Opuscula Theologica et Polemica: PG 91, 276A.

${ }^{41}$ Blowers (Paul M. Blowers, "Aligning and Reorienting the Passible Self: Maximus the Confessor's Virtue Ethics", in Studies in Christian Ethics, no.3/ 2013, p. 185) shows that Maximus understood diastema as designating spatio-temporal extension (Ambiquorum liber10: PG 91, 1157A). 
philosophers, is a self-existing thing, which doesn't need anything else to constitute itself. According to the Fathers, says Maximus, ovं $\sigma i$ í is the natural being of many and different hypostases. Maximus leans on the Cappadocian differentiation between essence and hypostasis, wherein hypostasis is equal to personality. The concept of personality appears in a strictly ontological meaning. Maximus says: "Hypostasis is, according to the philosophers, ousia with idiomata. But according to the Fathers, it is the particular man as distinct prersonally from the other man"42. Essence and nature, as is noted by Balthasar, don't have a consistent abstract meaning and cannot be understood as simply contrary to existence $^{43}$. Hypostasis is the way nature exists ( $\tau \rho{ }_{0} \pi \circ \varsigma$ v $\pi \alpha ́ \rho \xi \varepsilon \omega \varsigma$ ) and cannot exist without nature, just as nature cannot exist without

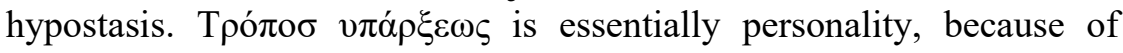

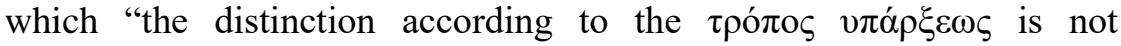
separating but unifying" ${ }^{\prime 4}$. Nature, therefore, exists in a hypostatical way.

In The Disputation with Pyrrhus, Pyrrhus presented the argument that the human will of Christ cannot be natural, because natural things are always a necessity ( Maximus responds: "Not only does the divine and un-created nature

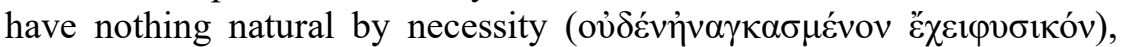

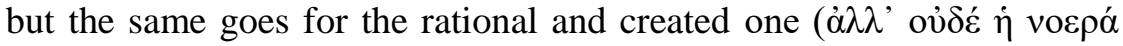

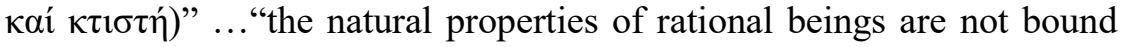

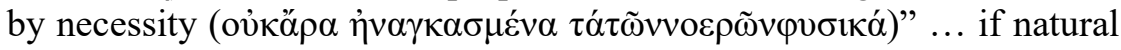

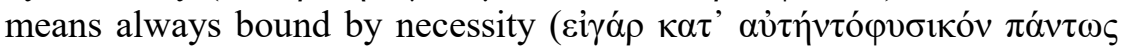

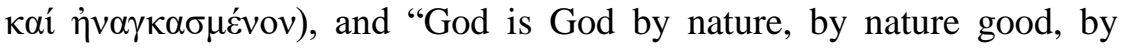
nature creator, then it means that God is bound by necessity to be God

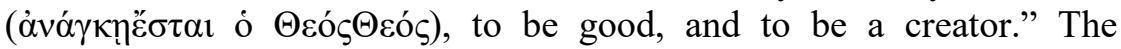
question arises - how to harmonize Maximus' claims about the tyranny of nature with the claim that nature does not imply necessity? To understand this problem, we have to remember that Maximus takes over

42 OpusculaTheologica et Polemica 16: PG 91, $276 \mathrm{~B}$.

${ }^{43}$ Hans Urs von BALthasar, Cosmic Liturgy - The Universe According to Maximus the Confessor, San Francisco: Ignatius Press, 2003, p. 225.

44 Panayiotis Christou, "Maximos Confessor on the Infinity Of Man",Actes du Symposium sur Maxime le Confeseur (Fribourg, 2-5 september 1980), (eds. F. Heinzer, C. Scönborn), Éditions Universitaires, Fribourg Suisse, 1982, p. 266. 
the Cappadocian triadological terminology which gives the ontological priority to hypostasis in relation to nature. Since nature is always hypostasized, it cannot, in relation to God and rational beings, be looked at neither separately nor statically. The nature Maximus talks about is not a static given. Neither God nor rational beings are without the aspect of will. The natural will shows the ecstatic potential of nature. In the case of created beings that ecstatic potential is the possibility to overcome natural limits through a change in the way of existence, which is why Maximus constitutes his iconic ontology.

\section{Iconic ontology}

In Maximus' Letter to Marinus, in the scholia, we find an interesting claim, which says that "essence is logos by icon" (Ovंoí $\alpha$

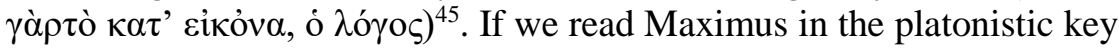
in which logoi are the same as ideas, this claim could mean that the essences of beings are the icons of their logoi as a reflection of some higher reality. Such interpretation is not in accord with Maximus' equalization of the logoi with the wishes of God or His intentions, of which we wrote earlier on. Maximus himself gives us explanations which sound platonistic, but are essentially different from them. He says: "all present goods are in comparison to the ones to come only mirror images of their logoi. They are therefore only icons of their true Archetype, still not having their own image fully realized..."46. We see that the present goods are only mirror images of their logoi. But those logoi are not something that exists objectively - only in the future will there be authentic expressions of the logoi of God. When history is eschatologically fulfilled, we will be able to say that the logoi of God are realized. Therefore, icon isn't understood as a mirror or paradigm, but as the real truth of being. Everything that is not in accord with the logoi will not exist, so the future is the final measurement of the present. The present dissemination, which is the mortal way of existence, will be overcome by unity. One nature has been "disseminated into many parts

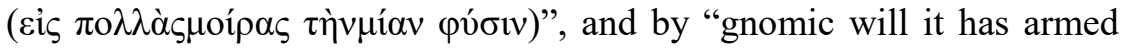

${ }^{45}$ PG $91,37 \mathrm{BC}$.

${ }^{46}$ Questiones ad Thalassium 46: PG 90, 420B. 


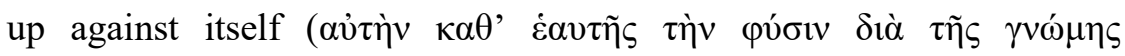
$\dot{\varepsilon} \xi \omega \pi \lambda(\sigma \varepsilon) "$. Christ is the one who harmonized gnomic will with nature,

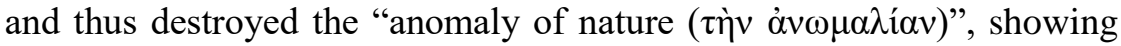
in himself which is the true "way of existence of logoi in the icon of

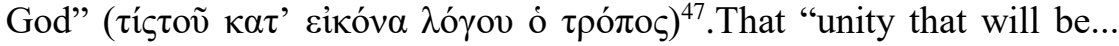
which we now anticipate and have in icon... to overcome the last enemy above us - death" ${ }^{48}$. This way, Maximus constitutes an iconic ontology. His iconic ontology is not eschatological in a linear way, since the Eschaton is already present in icon, which is why the basic context of Maximus' iconology is ecclesiological: "The same way the holy Church of God will be shown to perform in us deeds similar to deeds of God, since it is his icon and archetype" 49 . The iconic presence of Eschaton is real, since it in history paves the base for the real truth of being, which is a thing of the future age.

\section{References}

1. Balthasar, Hans Urs von, Cosmic Liturgy - The Universe According to Maximus the Confessor, San Francisco, Ignatius Press, 2003.

2. Blowers, M. Paul, "Aligning and Reorienting the Passible Self: Maximus the Confessor's Virtue Ethics", in Studies in Christian Ethics, no.3/2013, p. 333-350.

3. PANAYIOTIS, Christou, "Maximos Confessor on the Infinity Of Man", Actes du Symposium sur Maxime le Confeseur (Fribourg, 2-5 september 1980), (eds. F. Heinzer, C. Scönborn), Éditions Universitaires, Fribourg, Suisse, 1982.

4. HARRISON, Nonna Verna, "The human person as image and likeness of God", in The Cambridge Companion to Orthodox Christian Theology (Edited by Mary B. Cunningham and Elizabeth Theokritoff), Cambridge University Press, 2009, p. 78-92.

5. IVAnovic, Filip, Symbol \& Icon: Dionysius the Areopagite and the Iconoclastic Crisis, Wipf \& Stock Publishing, 2010.

6. JEANNOT, M. Thomas, "Plato and Aristotle on Being and Unity",The New Scholasticism, no. 4/1986, p. 404-426.

${ }^{47}$ Diversa Capita 1, 46: PG 90, 1196BC.

${ }^{48}$ Ambiquorum liber 7: PG 91, 1076A.

${ }^{49}$ Mystagogia 1, 3: PG 91, 665CD. 
7. KITTEL, Gerhard, Theological Dictionary of the New Testament, William B. Eerdmans Publishing Company, 1965.

8. LAMPe H. Geoffrey, A Patristic Greek Lexicon, Oxford University Press, 1969.

9. Loudovikos, Nikolaos, "Being and Essence Revisited: Reciprocal Logoi and Energies in Maximus the Confessor and Thomas Aquinas, and the Genesis of the Self-referring Subject", in Revista Portuguesa de Filosofia, no. 1/2016, p. 117-146.

10. Manoussakis, John Panteleimon, For the Unity of All: Contributions to the Theological Dialogue between East and West, Cascade Books, 2015.

11. McGuckin, A. John (ed.), The Westminster Handbook to Origen, Westminster John Knox Press, 2004.

12. RAmelli, Ilaria, The Christian Doctrine of Apokatastasis: A Critical Assessment from the New Testament to Eriugena, BRILL, 2013.

13. Rorem, Paul, "Iamblichus and the Anagogical Method in PseudoDionysius' Liturgical Theology", in Studia Patristica, no.1/1982, p. 453-460.

14. SöRBOM, Göran, "The Classical Concept of Mimesis", in A Companion to Art Theory (Eds. Paul Smith, Carolyn Wilde), WileyBlackwell, 2007, p.19-28.

15. STEWART, Columba, "Imageless Prayer and the Theological Vision of Evagrius Ponticus", in Journal of Early Christian Studies, no.2/2001, p. 173-204.

16. Voegelin, Eric, Plato, University of Missouri, 2000.

17. ZIZIOULAS, John, The Eucharistic Communion and the World, Bloomsbury T\&T Clark, 2011.

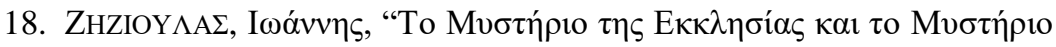

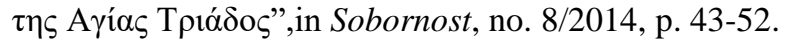

